\title{
ONLINE MARKETING BAGI UMKM DI DESA JANGGAN KECAMATAN PONCOL MAGETAN PROVINSI JAWA TIMUR
}

\author{
Titin Masfingatin ${ }^{1}$, Wasilatul Murtafiah ${ }^{2}$ \\ 1,2Universitas PGRI Madiun, Madiun, Indonesia \\ Email: titin.mathedu@unipma.ac.id
}

\begin{abstract}
Abstrak:
Pandemi covid 19 yang melanda semenjak bulan Maret 2020 hingga saat ini sangat berdampak bagi pelaku UMKM di Desa janggan Kecamatan Poncol Magetan. Produk yang biasanya dijual dengan cara konvensional, yaitu adanya pertemuan langsung antara penjual dan pembelikini terkendala pembatasan social akibat pandemic covid. Tujuan kegiatan pengabdian ini adalah untuk mengenalkan dan melatihkan pemasaran produk UMKM secara online di tokopedia. pelaksanaan pelatihan online marketplace bagi UMKM di Desa Janggan antara lain untuk membantu UMKM mengatasi masalah pemasaran produk karena pandemic Covid-19, memperkenalkan UMKM kepada e-commerce yang kini lebih diminati pembeli, serta meningkatkan perekonomian UMKM. Metode pelaksanaan program kerja ini meliputi sosialisasi dan pelatihan pengenalan aplikasi online marketplace, pembuatan akun, pengelolaan akun, menerima serta mengiriman produk. Aplikasi online marketplace yang dilatihkan ialah Tokopedia, dikarenakan mudah digunakan, memiliki banyak pengguna serta merupakan salah satu produk anak bangsa. Kepala Desa Janggan serta pada pemilik UMKM menyambut dengan antusias program pelatihan ini. Sasaran kegiatan ini adalah pelaku UMKM di Desa Janggan, yang terdiri dari 3 UMKM. Hasil dari pelatihan online marketplace ini adalah pelaku UMKM di desa Janggan telah memiliki akun toko online di tokopedia sebagai sarana untuk mempromisikan dan memasarkan produknya. Dengan adanya pelatihan online marketplace di Desa Janggan ini dapat mengembalikan perekonomian para pelaku UMKM yang mengalami penurunan karena pandemi.
\end{abstract}

Kata Kunci: Pemasaran online, UMKM, tokopedia

\section{Pendahuluan}

Pandemi covid-19 yang melanda hamper di seluruh wilayah di dunia. Di Indonesia masyarakat sangat merasakan dampak adanya pandemic ini. Masyarakat harus mematuhi protocol kesehatan agar penularan covid 19 dapat ditekan. Protocol kesehatan ini dikenal dengan istilah 3M yang berkembang menjadi 5M, yaitu mencuci tangan, memakai masker, menjaga jarak, menghindari kerumunan dan mengurangi mobilitas. Adanya protocol kesehatan ini sangat mempengaruhi kegiatan perekonomian masyarakat yang lebih banyak melakukan aktivitas di luar ruangan.

Pandemic covid ini juga sangat dirasakan dampaknya oleh masyarakat Desa Janggan, Kecamatan Poncol Kabupaten Magetan. Desa ini terletak di lereng gunung Lawu Magetan Jawa Timur. Masyarakat desa Janggan sebagian besar bermatapencaharian sebagai petani/pekebun dan pedagang. Selain itu, sebagian masyarakat juga memiliki keahlian membuat alat-alat pertanian dari besi. Masyarakat yang memiliki keahlian pandai besi ini 
membentuk kelompok yang dinamai UMKM Maju Baja. UMKM ini diketuai oleh Bapak Somali, penduduk asli Desa Janggan.

Pada masa sebelum covid melanda, masyarakat telah mampu memproduksi alat-alat pertanian, seperti sabit, pisau, cangkul dan sebagainya. Menurut informasi dari bapak kepala desa Janggan, produk-produk UMKM Maju Baja menjadi komoditas utama desa Janggan. Kualitas produk yang dihasilkan UMKM Maju Baja ini sudah dikenal di pasaran. Penjualannya pun juga sudah sampai ke luar daerah. Banyak pembeli yang datang dari luar daerah yang dating langsung ke lokasi untuk membeli atau memesan alat-alat pertanian.

Indonesia yang sebagian besar penduduknya merupakan petani pasti sangat memerlukan alat-alat pertanian. Oleh sebab itu, pemasaran produk alat-alat pertanian ini sangat memberikan peluang berkembangnya UMKM Maju Baja. Adanya pandemic covid memberikan dampak sangat signifikan terhadap penjualan produk dari UMKM Maju Baja. Penjualan produk UMKM ini turun drastic, hingga mencapai lebih dari 50\%. Pasar tempat pemasaran produk UMKM ini menjadi sepi. Hal ini menunjukkan bahwa pemasaran produk UMKM ini belum menyeluruh, hanya masyarakat yang tertentu saja atau yang sudah mengenal produk ini saja yang mengetahui produk UMKM ini. Permasalahan yang sama juga terjadi di beberapa UMKM (Endriastuti and Permatasari, 2018; Hendriadi, Sari and Padilah, 2019). Akibatnya penjualan berkurang.

Selama ini pemasaran hanya dilakukan secara tatap muka langsung dengan pembeli. Masyarakat belum mengenal adanya system pemasaran secara online. Penjualan produk secara online sangat penting bagi UMKM, agar produk-produk yang dihasilkan dikenal oleh masyarakat luas (Maftuhah and Rafsanjani, 2019). E-commerce memiliki banyak manfaat terhadap UMKM dengan memperluas peluang perusahaan di pasar, meningkatkan penjualan, meningkatkan komunikasi, meningkatkan citra perusahaan, mempercepat proses, dan meningkatkan produktivitas karyawan (Rahayu,2017). Teknologi online marketplace ini lah yang dapat sangat membantu para pemilik UMKM dimasa pandemi Covid-19 seperti ini, dimana seluruh kegiatan perkumpulan yang ada diminimalisir.

Masyarakat desa Janggan telah melek teknologi. Hal ini dapat dilihat dari hamper semua warga telah memiliki smartphone sebagai sarana berkomunikasi. Penggunaan smartphone hanya sebatas berbagi informasi dan komunikasi melalui telepon, pesan singkat atau media social berupa whatsapp atau yang lainnya. Masyarakat belum memiliki kemampuan untuk memanfaatkan smartphone sebagai sarana memasarkan/menjual produknya.

Penjualan produk secara online memiliki banyak kelebihan. Proses penjualan dapat dilakukan kapan pun dan dimana pun tanpa terbatas ruang dan waktu. Penjual dan pembeli dapat melakukan transaksi jual-beli tanpa harus tatap muka, yang dapat melanggar protocol kesehatan. Proses jual beli dapat berlangsung meskipun dalam keterbatasan akibat pandemic covid 19.

Penjualan produk secara online dengan memanfaatkan jaringan internet disebut juga m- 
commerce. M-commerce (Mobile commerce) merupakan transaksi dan komunikasi elektronik yang dilakukan dengan menggunakan mobile (seperti: laptop, PDA, telepon seluler dll) dan pada umumnya menggunakan jaringan nirkabel (Endriastuti and Permatasari, 2018). Salah satu mcommerce yang dapat diskses dengan mudah oleh masyarakat adalah tokopedia. website Tokopedia merupakan mall online yang menyediakan bisnis online dengan mudah, sekaligus memberi pengalaman belanja online yang aman dan nyaman(Lupi and Nurdin, 2016).

Tujuan kegiatan pengabdian ini adalah untuk mengenalkan strategi pemasaran berbasis online melalui Tokopedia kepada pelaku UMKM Maju Baja di Desa Janggan Kecamatan Poncol Kabupaten Magetan. Melalui kegiatan pengabdian ini masyarakat dapat memiliki pengetahuan dan kemampuan untuk membuka toko online di Tokopedia dan memasarkan produk UMKM Maju baja di Tokopedia. Kegiatan pengabdian masyarakat ini dapat membantu masyarakat yang terkendala pemasaran produk akibat pandemic covid 19.

\section{Metode}

Pengabdian kepada masyarakat ini dilaksanakan melalui tiga tahapan, yaitu analisis permasalahan mitra, Identifikasi dan perumusan masalah, pelaksanaan, evaluasi dan tidak lanjut. Analisis permasalahan dilaksanakan melalui survey lokasi dan interview. Hasil analisis permasalahan selanjutnya diidentifikasi dan dirumuskan suatu focus permasalahan yang akan diselesaikan melalui program pengabdian. Pelaksanaan meliputi sosialisasi program dan pelatihan program. Setelah kegiatan selesai dilakukan evaluasi dan pendampingan sebagai tindak lanjut.

Subjek yang menjadi sasaran program pengabdian masyarakat ini adalah pemilik UMKM Maju Baja desa Janggan Kecamatan Poncol Magetan. Pelaksanaan kegiatan melalui sosialisasi dan pelatihan program bagi pelaku UMKM Maju Baja. Indikator ketercapaian program adalah dilihat dari kemampuan subjek untuk membuka toko secara online dan memasarkan produk secara online. Alur pelaksanaan kegiatan pengabdian ini seperti disajikan pada Bagan 1. Berikut.

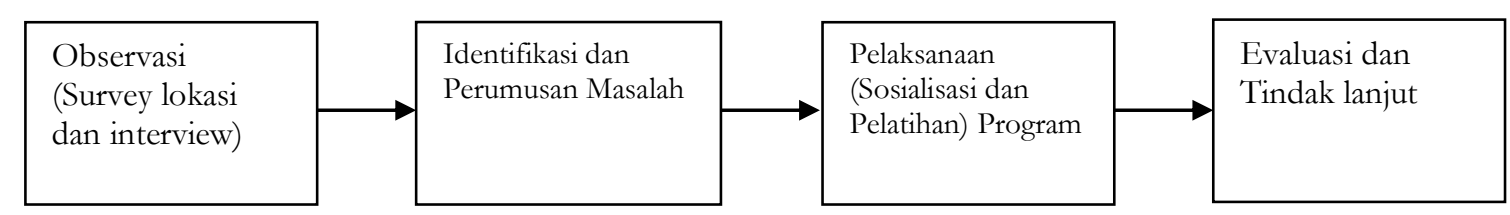

Bagan 1. Kerangka alur Kegiatan pengabdian masyarakat

\section{Hasil dan Pembahasan}

Kegiatan pelatihan pembuatan online marketplace Tokopedia dilakukan pada tanggal 15 dan 16 Januari 2021 berlokasi di rumah Pak Somali pemilik UMKM Maju Baja di Desa Janggan. Pelatihan ini diikuti tiga pemilik UMKM kreatif yang ada di Desa Janggan. Pertama, 
UMKM tersebut bergerak dalam bidang produksi kerajinan besi seperti golok, cangkul, sabit, dan peralatan tukang lainnya, kedua UMKM pengrajin kayu yang memproduksi telenan, centong, sutil, spatula dan peralatan dapur lainnya, serta UMKM pemanfaatan limbah bongkol jagung yang diolah menjadi pakan ternak. Masing-masing UMKM diwakili oleh 2 orang yang mengikuti kegiatan pelatihan.

Kegiatan dilaksanakan selama dua hari, yaitu Jumat-Sabtu tanggal 15 dan 16 Januari 2021. Jadwal kegiatan pengabdian disajikan pada Tabel 1. berikut.

Tabel 1. Jadwal Kegiatan Pelaksanaan Program

\begin{tabular}{lcl}
\hline No. & Hari, Tanggal & \multicolumn{1}{c}{ Kegiatan } \\
\hline 1 & Jumat, 15 Januari 2021 & - Sosialisasi dan pengenalan aplikasi toko online \\
& & tokopedia \\
& - & Pengenalan fitur-fitur dalam tokopedia \\
\hline 2 & Sabtu, 16 Januari 2021 & Pelatihan Pembuatan online market (toko online) di \\
& & tokopedia \\
& - Pelatihan pemasaran produk di tokopedia \\
& - Pelatihan cara mengoperasikan toko yang telah \\
& dibuat \\
& - & Tata cara menerima pesanan dan pengelolaan toko \\
& & online. \\
\hline
\end{tabular}

Hasil yang dicapai adalah para peserta telah mengenal aplikasi tokopedia, mampu mendownload dan mengakses aplikasi tersebut di mobile phone masing-masing. Para peserta juga telah mengenal fitur-fitur dalam aplikasi. Masing-masing UMKM telah mampu membuat online shop di tokopedia. Salah satu contoh online shop yang telah dibuka pada Gambar 1.

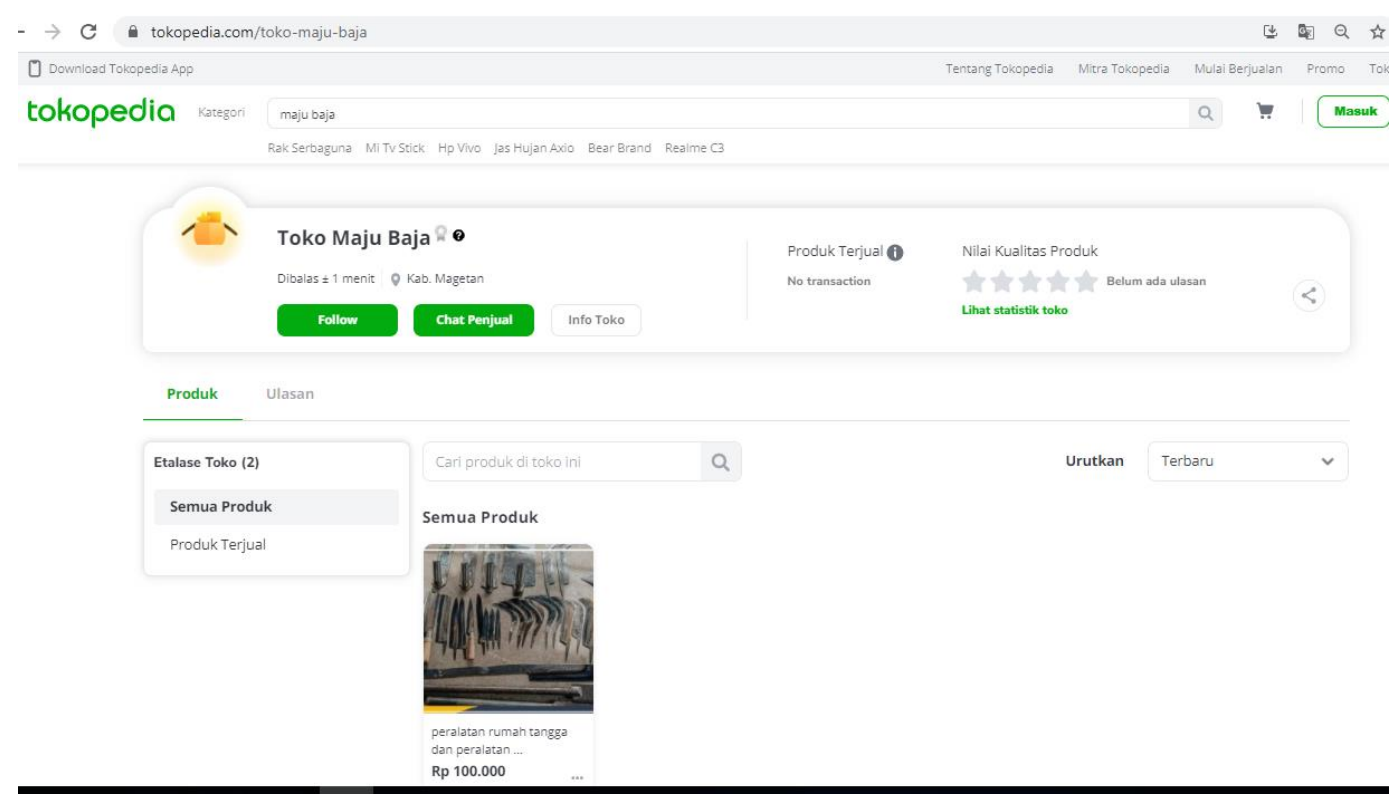

Gambar 1. Toko Maju Baja di Tokopedia 
Pelatihan pemasaran produk UMKM secara online ini juga telah dilaksanakan di Kabupaten Karawang (Hendriadi, Sari and Padilah, 2019). Hasil kegiatan ini senada dengan hasil pada kegiatan tersebut, yaitu pelaku UMKM telah memiliki kemampuan untuk menjalankan toko online. Masyarakat dapat mengenalkan dan mempromosikan produknya dengan cepat dan jaringan yang luas. Masyarakat dapat menjual produknya tanpa harus bertatapmuka dengan pembeli. Ini sangat menguntungkan pelaku UMKM dalam situasi pandemic covid 19.

Setelah pelatihan ini diharapkan adanya peningkatan kemampuan pemilik UMKM dalam penggunaan online marketplace untuk menjalankan usahanya. Sebagai tindaklanjut dari kegiatan ini akan dilakukan pendampingan program dengan pemberian buku pedoman penggunaan tokopedia bagi UMKM di Desa Janggan.

\section{Kesimpulan}

Pemasaran produk UMKM di Desa Janggan telah memperoleh solusi berupa pemasaran secara online di tokopedia. Pelaku UMKM telah memiliki akun atau toko online untuk memasarkan dan mempromosikan produknya pada masa pandemic covid 19. Saran yang dapat disampaikan adalah agar pelaku UMKM terus menggali pengetahuan untuk pengelolaan toko online di Tokopedia atau marketplace yang lain. Hal ini bertujuan agar produk UMKM dapat dikenal masyarakat lebih luas dan dapat memperkuat ekonomi kerakyatan masyarakat desa Janggan Kecamatan Poncol Magetan.

\section{UcapanTerima Kasih}

Ucapan terimakasih kami sampaikan kepada Bapak Hariadi selaku kepala desa Janggan yang telah mendukung dan mendampingi kegiatan ini sampai selesai. Bapak Somali sebagai pelaku UMKM yang selalu bersemangat untuk belajar demi kemajuan UMKM di Desa Janggan. Kami juga mengucapkan terimaksih kepada LPPM Universitas PGRI Madiun sebagai penyangga dana sehingga terselenggaranya kegiatan ini.

\section{Referensi}

Endriastuti, A. and Permatasari, M. P. (2018) 'Pelatihan Pemasaran, Pemberdayaan Toko Online, dan Pengenalan m-commerce Pada Produk Unggulan Jagung Tortila di Kecamatan Trucuk Kabupaten Bojonegoro', Martabe: Jurnal Pengabdian Kepada Masyarakat, 1(2), p. 56. doi: 10.31604/jpm.v1i2.56-66.

Hendriadi, A. A., Sari, B. N. and Padilah, T. N. (2019) 'Pelatihan Digital Marketing Usaha Mikro, Kecil dan Menengah (UMKM) di Kabupaten Karawang', J-Dinamika: Jurnal Pengabdian Masyarakat, 4(2), pp. 120-125. doi: 10.25047/j-dinamika.v4i2.1133.

Lupi, F. R. and Nurdin (2016) 'Analisis strategi pemasaran dan penjualan', Jurnal Elektronik Sistem Informasi dan Komputer, 2(1), pp. 20-31. Available at: 
https:/ / scholar.google.co.id/scholar?hl=en\&as_sdt=0\%2C5\&as_vis=1\&q=sistem + info rmasi+tokopedia\&btnG $=\# \mathrm{~d}=\mathrm{gs} \_q a b s \& u=\% 23 \mathrm{p} \% 3 \mathrm{DFOIp} 4 X F Z Z F I J$.

Maftuhah, R. and Rafsanjani, H. (2019) 'Pelatihan Strategi Pemasaran Melalui Media Online Pada Produk Usaha Rumahan Krupuk Bawang dan Kripik Sukun', Aksiologiya: Jurnal Pengabdian Kepada Masyarakat, 3(2), p. 227. doi: 10.30651/aks.v3i2.1996. 